\title{
Adducts of Lower Fullerenes and Amino Acids: Synthesis, Identification, and Quantum-Mechanical Modeling of Their Physicochemical Properties
}

\author{
N. A. Charykov ${ }^{a, b}$, V. A. Keskinov ${ }^{a, *}$, and A. V. Petrov ${ }^{c}$ \\ ${ }^{a}$ St. Petersburg State Institute of Technology, St. Petersburg, 190013 Russia \\ ${ }^{b}$ St. Petersburg Electrotechnical University (LETI), St. Petersburg, 197022 Russia \\ ${ }^{c}$ St. Petersburg State University, St. Petersburg, 198504 Russia \\ *e-mail: keskinov@mail.ru \\ Received April 9, 2021; revised May 8, 2021; accepted May 11, 2021
}

\begin{abstract}
Different ways of synthesizing bis-, tris-, and octakis-adducts of $\mathrm{C}_{60}$ and $\mathrm{C}_{70}$ lower fullerenes are considered, and their yield and purity are described. The adducts are identified by physicochemical means: elemental analysis, IR, electron spectroscopy, Raman spectroscopy, HPLC, mass spectrometry, and complex thermal analysis. Their physicochemical properties are modeled using computers, density functional theory, and molecular dynamics at the atomic-molecular level.
\end{abstract}

Keywords: bis-adducts, tris-adducts, octakis-adducts, lower fullerenes, amino acids, lysine, threonine, arginine, hydroxyproline, elemental analysis, IR, electron and Raman spectroscopies, HPLC, mass spectrometry, complex thermal analysis, density functional analysis, molecular dynamics

DOI: $10.1134 / \mathrm{S} 0036024421120049$

\section{INTRODUCTION}

Fullerenes, which have unique chemical and physical properties, have drawn the attention of many researchers since their discovery in 1985 , due to their wide use in industry [1]. They are, however, incompatible with water and aqueous solutions [2-5], which considerably limits their use. The solubility of $\mathrm{C}_{60}$ in water is only $0.02 \mathrm{ng} / \mathrm{L}$ [2], which is also observed for most derivatives of lower fullerenes (fluoro-, chloro-, bromo-, iodo-, oxo-, amino-, and carboxyl). These are usually very poorly soluble in water and solutions [5-7]. At the same time, water-soluble fullerene derivatives are widely used in mechanical engineering, construction, medicine, pharmacology (due to their good compatibility with water, physiological solutions, blood, lymph, and gastric juice), cosmetology (in aqueous and water-alcohol solutions), science, and technology. Among the many ways in which they have been studied in these fields, the preparation of stable aqueous fullerene dispersions $[8,9]$ (the size of fullerene clusters depends on the procedure and varies in the nanometer range) and stable complex associates with hydrophilic substances [3, 4, 10-12] are worthy of note. In both cases, the stability of systems depends strongly on their environment. In addition, such products are not individual substances, so their use as initial reagents to obtain different water-soluble fullerene adducts is unacceptable [13]. The third way of fullerene functionalization is to add hydrophilic groups to a fullerene core (i.e., prepare adducts). This technique is the one most versatile, due to the weakly conjugated double bonds in fullerenes and their high tendency to react at double bonds (nucleophilic and radical addition reactions). Most of the adducts formed by these ways are fairly stable, allowing the use of further chemical modifications to obtain new biologically active substances [13]. The most common reactions in fullerene chemistry are cycloaddition, which are known in organic chemistry as Diels-Alder diene synthesis, where $\mathrm{C}_{60}$ always participates as a dienophile [3, 14]. Reactions of the one-stage addition of primary and secondary amines, and direct addition of amino acids and dipeptides to fullerene, proceed according to a radical mechanism [15, 16]. The resulting compounds are stable and physiological, since natural amino acids are used in their synthesis. This was confirmed by biological tests in the late 1990s and after [17-19]. From the biological and chemical points of view, one of the most important problems in using fullerenes is therefore preparing water-soluble fullerene compounds and derivatives of them that are based on different amino acid matrices. The present work is devoted to this problem. 


\section{SYNTHESIS AND IDENTIFICATION OF ADDUCTS OF LOWER FULLERENES WITH AMINO ACIDS}

Different classes of water-soluble fullerene derivatives have so far been synthesized. These include fullerenols and their esters with carboxylic and dicarboxylic acids, with amino acids, and with peptides and proteins [15-53]. Along with several $\mathrm{C}_{60}$ monofunctional derivatives containing polar side chains, polyamino and polyhydroxyl fullerenes were studied as in early as in the first half of the 1990s [27, 28]. A large number of polyhydroxylated fullerene derivatives, tested in different chemical and biological model systems and displaying both antioxidant and prooxidative properties, were described in [53]. Several mechanisms were proposed for the antioxidant activity of fullerenols, and patents relating to antioxidant properties of fullerenol were filed. The first work by Hirsch et al. on fullerenes containing multiple covalently bound substituents of an amine derivative appeared in 1991 [15]. All derivatives displayed high solubility in water [15-30]. The authors showed that the higher the number of water-soluble groups added to fullerene, the stronger its water solubility. The main problem in synthesizing water-soluble fullerene adducts with hydrophilic compounds (amino acids and peptides) is the incompatible solubility of reaction components (very hydrophobic fullerenes and hydrophilic amino acids). Aprotic non-polar environments are needed to dissolve fullerenes, while polar aqueous ones are required for amino acids. The heterogeneity of a reaction system prolongs the reaction time and lowers the yield of the target product. If heating is used, it can racemize an added addend (e.g., an amino acid or peptide) [13].

A way of synthesizing a functionalized fullerene with symmetric polar organic fragments and 1 to 20 carbon atoms with optional oxygen or nitrogen was patented in the United States in 2001 [54]. It should, however, be considered purely preparative, due to its complexity and multistage nature. The preparation of amino acid adducts (lysine derivative) by synthesizing a aminocaproic acid fullerene derivative and subsequently adding it to a lysine derivative of a glycopeptide was first patented in [55]. Salts of aminocaproic and aminobutyric acids with alkali metals were used in reactions with fullerene as 18 -crown- 6 complexes. The system was heterogeneous: $o$-dichlorobenzene and water heated at $60^{\circ} \mathrm{C}$ for $6-8 \mathrm{~h}$. The solvents were then distilled off, and the residue was treated with a saturated solution of potassium chloride and water.

Many fullerene derivatives with amino acids have been studied theoretically. The ability of $\mathrm{C}_{60}$ fullerene to interact with amino acids was studied at the theoretical level in [56]. Calculations performed at the DFT-B3LYP/3-21G level of theory showed that the best interactions were between fullerene and arginine, leucine, and tryptophan, due to the framework structure of these amino acids. The molecular structures of
$\mathrm{C}_{60}$ hybrid amino acid derivatives were determined via quantum-chemical calculations [57]. Calculations used to study amino acid fullerenes derivatives at the atomic and molecular levels are described more thoroughly below.

Both $\mathrm{C}_{60}$ and $\mathrm{C}_{70}$ fullerenes functionalized with amino acids were synthesized and studied in subsequent years to identify them and determine their purity and physicochemical properties [58-81]. Some works described the biological activity of water-soluble amino acid fullerene derivatives [9, 29, 82-86].

Fullerene $\mathrm{C}_{60}$ amphiphilic derivatives with alanine, cysteine, and arginine were synthesized and characterized in [45]. The authors concluded that fullerene $\mathrm{C}_{60}$ derivatives with amino acids can prevent oxidative stress-induced cell death without obvious toxicity. A fullerene $\mathrm{C}_{60}$ derivative with lysine was synthesized and its biological activity was studied in [50]. The authors of [51] synthesized a glycine fullerene $\mathrm{C}_{60}$ derivative. Studies of the cytotoxicity of this derivative on lines of cancer cells showed that kills them. The neuroprotective properties of hybrid structures based on $\mathrm{C}_{60}$ and proline derivatives were studied in $[18,78]$. The authors found that each compound had antioxidant activity and suppressed the glutamate-induced adsorption of $\mathrm{Ca}^{2+}$ ions in the synaptosomes of a rat's cerebral cortex.

Most works describe $\mathrm{C}_{60}$ fullerenes. Much fewer deal with the synthesis of derivatives of $\mathrm{C}_{70}$ fullerene. Their biological action and physicochemical properties can differ considerably, despite their apparent similarity $[80,81]$.

It should be noted that a great many works provide no means of synthesis or identifying data for derivatives. They also describe few physicochemical properties of fullerene derivatives, despite their importance in optimizing and developing the most promising practical uses of carbon nanoclusters. Ways of synthesizing fullerene derivatives are also mostly preparative and allow the production of only milligram quantities, while data on the biological activity of fullerene derivatives are not compared and no relationships between them and physicochemical properties are revealed [87].

Figure 1 shows the structural formulas of some $\mathrm{C}_{60}$ amino acid adducts. Table 1 shows schemes for synthesizing various amino acid fullerene adducts with specific stoichiometric compositions and ways of identifying them. These include IR spectroscopy, Raman spectra, electron spectroscopy, nuclear magnetic resonance, high performance liquid chromatography, liquid chromatography-mass spectrometry, elemental analysis, and (less often) and thermal analysis with mass spectrometry. Figures $2-6$ and Table 2 show some ways of identifying adducts [87]. 


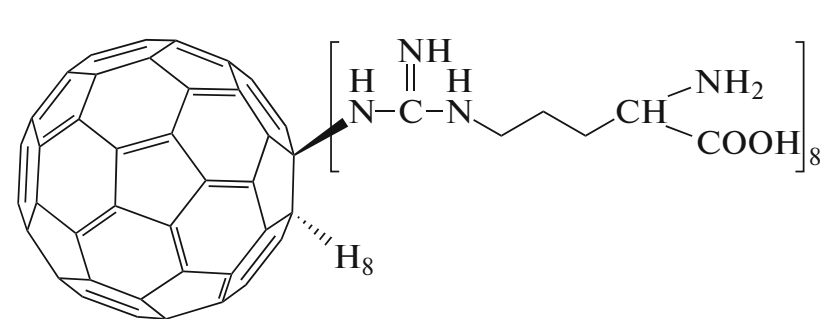

(a)

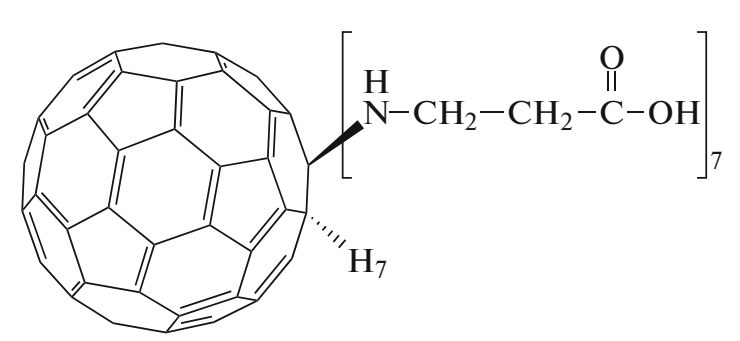

(c)

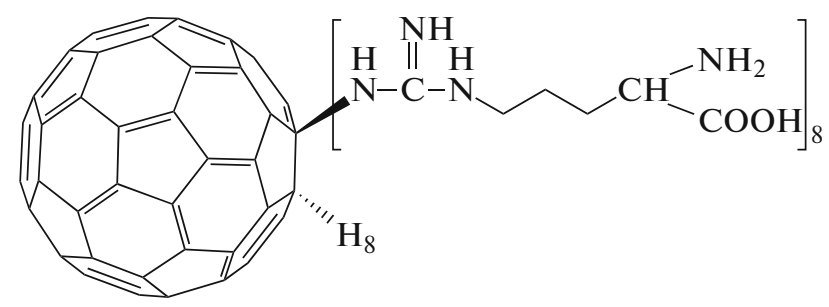

(e)

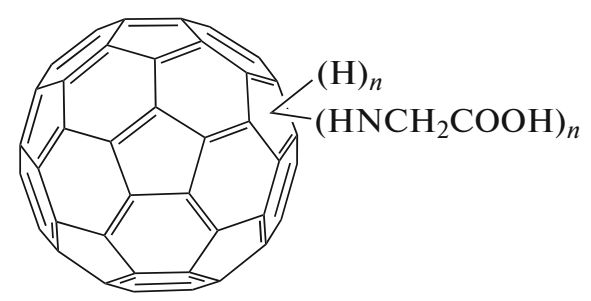

(g)

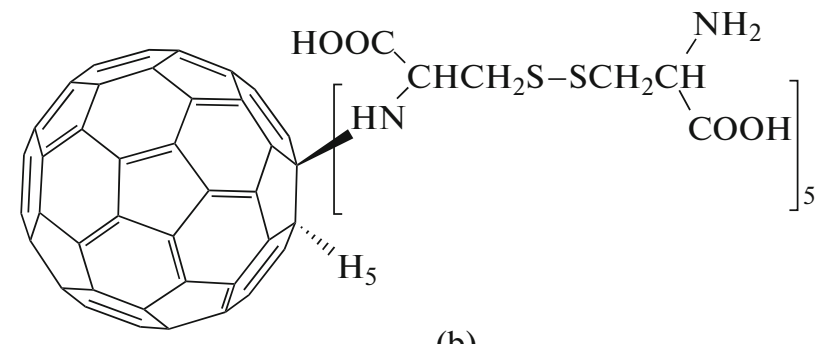

(b)

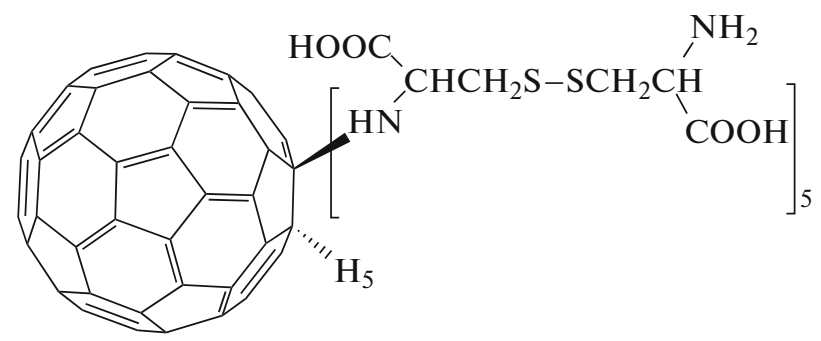

(d)

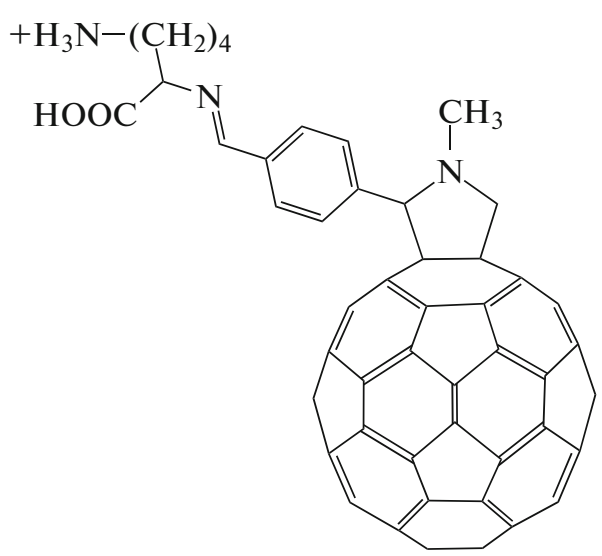

(f)

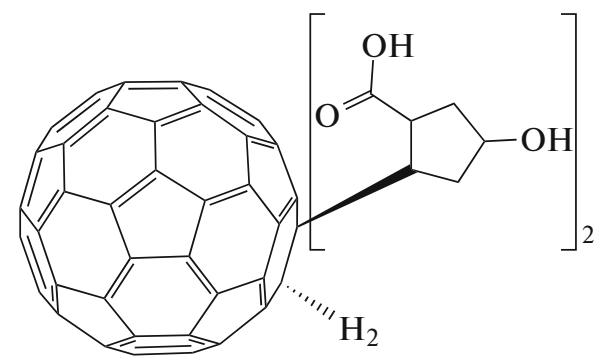

(h)

Fig. 1. Structural formulas of some $\mathrm{C}_{60}$ amino acid adducts.

\section{COMPUTER MODELING}

OF THE PHYSICOCHEMICAL PROPERTIES OF AMINO ACID FULLERENE DERIVATIVES

The main theoretical ways of studying amino acid fullerene derivatives and calculating their physicochemical properties are density functional theory (DFT) and molecular dynamics. Application of DFT is based on the relationship between the properties of molecules and their electronic structure. Properties of simulated systems in molecular dynamics are determined mainly by intermolecular interactions which indirectly (through force fields), also depend on the electronic structure.

Heat capacity was first calculated for a fullerene derivative with amino acid $\mathrm{C}_{60}-\mathrm{Arg}$ in [65] using a 
Table 1. Synthesis and identification of lower fullerene $\left(\mathrm{C}_{60}\right)$ amino acid adducts

\begin{tabular}{|c|c|c|c|c|}
\hline No. & $\begin{array}{l}\text { Amino acid and } \\
\text { adduct }\end{array}$ & Synthesis & $\begin{array}{l}\text { Methods and conditions } \\
\text { of identification }\end{array}$ & Ref. \\
\hline 1 & $\begin{array}{l}\text { Arginine and } \\
\mathrm{C}_{60}\left(\mathrm{C}_{6} \mathrm{H}_{13} \mathrm{~N}_{4} \mathrm{O}_{2}\right)_{8} \mathrm{H}_{8} \\
\text { (Fig. 1a) }\end{array}$ & Manufactured by ZAO ILIP & $\begin{array}{l}99.5 \mathrm{wt} \% \text { purity, } \\
\text { IR and UV spectroscopy, mass spec- } \\
\text { trometry, and elemental analysis }\end{array}$ & {$[42,43]$} \\
\hline 2 & $\begin{array}{l}\text { Alanine and alanyl- } \\
\text { alanine, } \\
\mathrm{C}_{60}\left(\mathrm{C}_{3} \mathrm{H}_{6} \mathrm{NO}\right) \text {, and } \\
\mathrm{C}_{60}\left(\mathrm{C}_{6} \mathrm{H}_{12} \mathrm{~N}_{2} \mathrm{O}_{3}\right)\end{array}$ & $\begin{array}{l}\text { The modifying effect } \mathrm{C}_{60} \text { water-soluble } \\
\text { derivatives with DL-alanine and DL-alanyl- } \\
\text { DL-alanine have on the structure and per- } \\
\text { meability of a lipid bilayer of phosphatidyl- } \\
\text { choline liposomes was studied [16] }\end{array}$ & None; refs. [16, 45] & [44] \\
\hline 3 & $\begin{array}{l}\beta \text {-Alanine, cysteine, } \\
\text { and arginine } \\
\text { (Figs. } 1 \mathrm{c}-1 \mathrm{e} \text { ) }\end{array}$ & $\begin{array}{l}\text { Adducts were prepared for other derivatives. } \\
\text { Amino acid ( } 10 \mathrm{mmol} \text { ) and sodium hydrox- } \\
\text { ide ( } 20 \mathrm{mmol} \text { ) were dissolved in } 3 \mathrm{~mL} \text { of } \\
\text { water, and then in ethanol }(10-20 \mathrm{~mL}) \text {. } \\
\text { The resulting solution was added dropwise to } \\
\left.\text { a } \mathrm{C}_{60} \text { toluene solution ( } 0.1 \text { mmol in } 60 \mathrm{~mL}\right) \text {, } \\
\text { then } 10 \% \text { tetrabutylammonium hydroxide } \\
\text { solution was added dropwise with stirring. } \\
\text { The solution was stirred at room temperature } \\
\text { for } 60 \text { h under a nitrogen atmosphere. } \\
\text { The aqueous layer was separated from the } \\
\text { organic layer and filtered. Then water ( } 3 \mathrm{~mL}) \\
\text { and ethanol ( } 40 \mathrm{~mL}) \text { were added to precipi- } \\
\text { tate the product, which was further reprecipi- } \\
\text { tated three times with } \mathrm{H}_{2} \mathrm{O} / \text { EtOH. } \\
\text { The product was then purified via size exclusion } \\
\text { chromatography on a dextran (G25, Pharma- } \\
\text { ceutical Biotech) } \mathrm{H}_{2} \mathrm{O} \text { column. The product } \\
\text { was eluted, with subsequent elution of the } \\
\text { unreacted amino acid and sodium hydroxide }\end{array}$ & $\begin{array}{l}\text { Not described; for earlier } \\
\text { works [46] }\end{array}$ & [46] \\
\hline 4 & $\beta$-Alanine (Fig. 1c) & $\begin{array}{l}\text { A preparation of } \mathrm{C}_{60} \beta \text {-alanine derivative [23]: } \\
1.5 \mathrm{~g} \text { of } \beta \text {-alanine and } 0.85 \mathrm{~g} \text { of sodium } \\
\text { hydroxide were dissolved in } 3 \mathrm{~mL} \text { of water, } \\
\text { and } 20 \mathrm{~mL} \text { of ethanol was added. The result- } \\
\text { ing solution was added to } \mathrm{C}_{60} \text { (a toluene } \\
\text { solution) }(55 \mathrm{mg} \text { in } 35 \mathrm{~mL}) \text { dropwise. } \\
\text { The solution was stirred at room temperature } \\
\text { under a nitrogen atmosphere. The solution } \\
\text { was stirred for } 48 \mathrm{~h} \text { to ensure the reaction was } \\
\text { complete. The aqueous layer was separated } \\
\text { from colorless organic layer, filtered, and } \\
\text { diluted with } 3 \mathrm{~mL} \text { of water. Then } 40 \mathrm{~mL} \text { of } \\
\text { ethanol was added to precipitate the product, } \\
\text { which was then re-precipitated with } \\
\mathrm{H}_{2} \mathrm{O} / \text { EtOH three times. The product was } \\
\text { further purified via HPLC on a dextran } \\
\text { ( } \mathrm{G}-25 \text {, Pharmacia Biotech) } \mathrm{H}_{2} \mathrm{O} \text { column. } \\
\text { The product was eluted first, followed by } \\
\text { unreacted } \beta \text {-alanine and sodium hydroxide. } \\
\text { A ninhydrin test showed there was } \\
\text { no free } \beta \text {-alanine in the product }\end{array}$ & $\begin{array}{l}\text { The product was characterized via } \\
\text { FTIR spectroscopy, }{ }^{1} \mathrm{H} \text { NMR, }{ }^{13} \mathrm{C} \\
\text { NMR, HPLC, and elemental analysis. } \\
\text { Analytical data of synthesized } \\
\text { and purified compound: } \\
\text { IR }(\mathrm{KBr}) \mathrm{v}: 3384(\mathrm{NH}), 2963(\mathrm{Ce}-\mathrm{H}) \text {, } \\
1575,1407\left(\mathrm{COO}^{-}\right), 1258,1048(\mathrm{C}-\mathrm{N}) \text {, } \\
599,528 \mathrm{~cm}^{-1}\left(\mathrm{C}_{60} \text { core); }\right. \\
{ }^{1} \mathrm{H} \mathrm{NMR}\left(\mathrm{D}_{2} \mathrm{O}\right), \delta \text { in ppm: } \\
2.27\left(\mathrm{~d}, \mathrm{CH}_{2}\right), 2.80\left(\mathrm{~d}, \mathrm{CH}_{2}\right), 3.56, \\
3.12,1.08\left(\mathrm{~m}, \mathrm{C}_{60}-\mathrm{H}\right) ;{ }^{13} \mathrm{C} \mathrm{NMR} \\
\left(\mathrm{D}_{2} \mathrm{O}\right) \delta \text { in ppm: } 180.7(\mathrm{~s}, \mathrm{COOH}), \\
165.0\left(\mathrm{~m}, \mathrm{C}_{60}\right), 37.5\left(\mathrm{~s}, \mathrm{CH}_{2}\right), 38.5(\mathrm{~s}, \\
\left.\mathrm{CH}_{2}\right) ; \mathrm{ESI}-\mathrm{MS} \mathrm{m} / z(\%): 1343\left(\mathrm{M}^{+},\right. \\
18.8), 1252(30.0), 1165(23.7), 1076 \\
(31.3), 985(13.7), 898(17.9), 809 \\
(7.95), 720(100) \text {. Calculated } \\
\mathrm{C}_{81} \mathrm{H}_{49} \mathrm{~N}_{7} \mathrm{O}_{14}: \mathrm{C} 72.38, \mathrm{H} 3.65, \mathrm{~N} \\
7.30 ; \text { found } \mathrm{C} 72.01, \mathrm{H} 3.59, \mathrm{~N} 7.34 \text {. } \\
\text { Results showed there were seven } \beta- \\
\text { alanine fragments per } \mathrm{C}_{60} \text { molecule }\end{array}$ & {$[46-48]$} \\
\hline
\end{tabular}


Table 1. (Contd.)

\begin{tabular}{|c|c|c|c|c|}
\hline No. & $\begin{array}{l}\text { Amino acid and } \\
\text { adduct }\end{array}$ & Synthesis & $\begin{array}{l}\text { Methods and conditions } \\
\text { of identification }\end{array}$ & Ref. \\
\hline 5 & Cysteine (Fig. 1b) & $\begin{array}{l}\text { Cysteine ( } 2.3 \mathrm{~g}) \text { and sodium hydroxide } \\
(0.85 \mathrm{~g} \text { ) were dissolved in } 5 \mathrm{~mL} \text { of water, and } \\
20 \mathrm{~mL} \text { of ethanol was added. The resulting } \\
\text { solution was added to toluene } \mathrm{C}_{60} \text { (solution) } \\
\text { ( } 60 \mathrm{mg} \text { and } 60 \mathrm{~mL} \text { ) dropwise, and } 5 \text { drops } \\
\text { of } 10 \% \text { tetrabutylammonium hydroxide was } \\
\text { added under stirring. The solution was stirred } \\
\text { at room temperature for } 48 \mathrm{~h} \text { under a nitro- } \\
\text { gen atmosphere. The solution was stirred } \\
\text { for } 60 \mathrm{~h} \text { to ensure the reaction was complete. } \\
\text { The aqueous layer was separated from the } \\
\text { organic layer, filtered, and diluted } \\
\text { with } 10 \mathrm{~mL} \text { of water; then } 60 \text { mL of ethanol } \\
\text { was added to precipitate the product, which } \\
\text { was subsequently re-precipitated three times } \\
\text { with } \mathrm{H}_{2} \mathrm{O} / \mathrm{EtOH} \text {. The product was then } \\
\text { further purified via size exclusion chromatog- } \\
\text { raphy on a dextran column (G-25, Pharma- } \\
\text { ceutical Biotech) with } \mathrm{H}_{2} \mathrm{O} \text {. The product } \\
\text { was eluted, with subsequent elution } \\
\text { of cystine and sodium hydroxide }\end{array}$ & $\begin{array}{l}\text { The compound was analyzed via } \\
\text { FTIR spectroscopy, }{ }^{1} \mathrm{H} \text { NMR, }{ }^{13} \mathrm{C} \\
\text { NMR, LC-MS, and elemental analysis. } \\
\text { IR(KBr) } v: 3425(\mathrm{NH}), 1623(\mathrm{C}-\mathrm{C}), \\
1586\left(\mathrm{COO}^{-}\right), 1405(\mathrm{C}-\mathrm{N}), 1194 \\
\left(\mathrm{~N}-\mathrm{C}_{60}\right), 656(\mathrm{C}-\mathrm{S}), 541(\mathrm{~S}-\mathrm{S}), 527 \\
\left(\mathrm{C}_{60} \text { core }\right), \mathrm{cm}^{-1} ;{ }^{1} \mathrm{H} \mathrm{NMR}\left(\mathrm{D}_{2} \mathrm{O}\right) \delta \\
\text { ppm: } 4.75(\mathrm{~s}), 3.91(\mathrm{~s}), \\
3.22(\mathrm{~s}), 3.27(\mathrm{~s}), 3.0(\mathrm{~m}) ;{ }^{13} \mathrm{C} \mathrm{NMR} \\
\left(\mathrm{D}_{2} \mathrm{O}\right) \delta \text { ppm: } 172.8,137-155,77.4- \\
76.8,52.2,51.4,49.7,32.7,32.5 ; \\
\mathrm{ESI}_{-} \mathrm{MS} m / z(\%): 1801\left(M^{+}-\right. \\
\left.\mathrm{C}_{3} \mathrm{H}_{6} \mathrm{NO} \mathrm{O}_{2} \mathrm{~S}, 14.4\right), 1783(86.4), 1642 \\
(10.3), 1440(13.8), 1328(22.7), 1154 \\
(21.7), 915(9.63), 840(21.8), 720 \\
(100) . \mathrm{Calculated} \mathrm{C}_{90} \mathrm{H}_{60} \mathrm{~N}_{10} \mathrm{O}_{20} \mathrm{~S}_{10} \text { : } \\
\mathrm{C} 56.25, \mathrm{H} 3.13, \mathrm{~N} 7.29 ; \\
\text { found C } 56.13, \mathrm{H} 3.19, \mathrm{~N} 7.34(\text { wt } \%) . \\
\text { Results showed there were five } \\
\text { cysteine fragments per } \mathrm{C}_{60} \text { molecule }\end{array}$ & [49] \\
\hline 6 & Lysine (Fig. 1f) & $\begin{array}{l}N \text {-protected fulleropyrrolidine ( } 30 \mathrm{mg} \text {, } \\
0.03 \mathrm{mmol} \text { ) was dissolved in a } 1: 1 \mathrm{mixture} \\
\text { of toluene/trifluoroacetic acid and stirred for } \\
12 \mathrm{~h} \text {. The reaction was monitored with HPLC } \\
\left(\mathrm{SiO}_{2} \text {; toluene/propanol, } 9: 1 \text { ). }\right. \\
\mathrm{After} \mathrm{complete} \mathrm{deprotection,} \mathrm{the} \mathrm{solvents} \\
\text { were evaporated. MeOH was added and } \\
\text { again evaporated. The residue was taken up } \\
\text { in } \mathrm{CH}_{2} \mathrm{Cl}_{2} \text {, and the solution was added drop- } \\
\text { wise to excess hexane. The precipitated solid } \\
\text { was separated via centrifugation, washed with } \\
\text { small amounts of Et } \mathrm{E}_{2} \mathrm{O} \text {, and dried under high } \\
\text { vacuum to yield a brownish solid. The yield } \\
\text { was } 25 \mathrm{mg}(83.3 \%) ; \mathrm{mp} .251^{\circ} \mathrm{C}\end{array}$ & 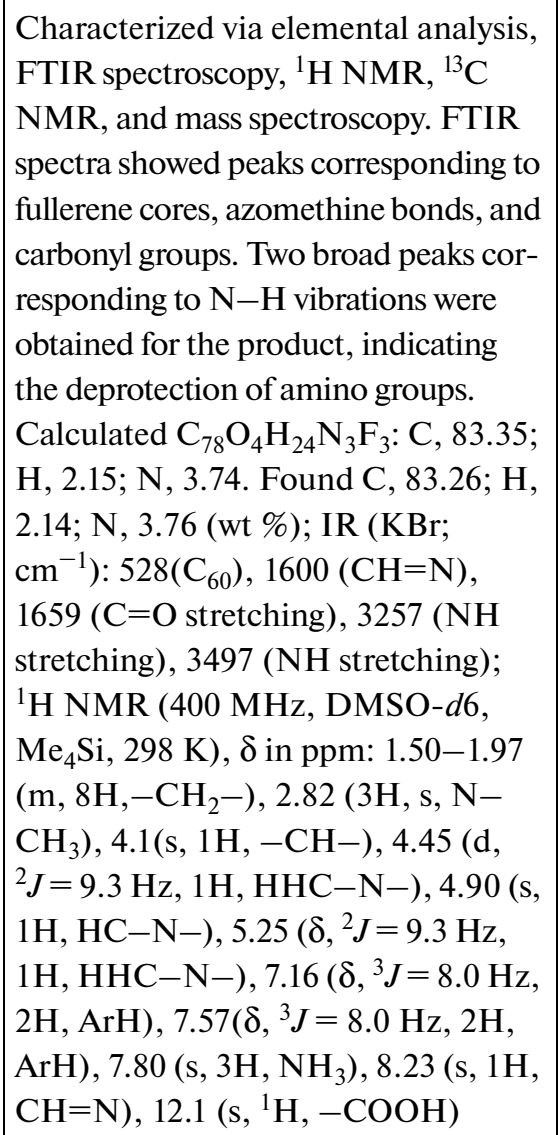 & {$[50]$} \\
\hline
\end{tabular}


Table 1. (Contd.)

\begin{tabular}{|c|c|c|c|c|}
\hline No. & $\begin{array}{l}\text { Amino acid and } \\
\text { adduct }\end{array}$ & Synthesis & $\begin{array}{l}\text { Methods and conditions } \\
\text { of identification }\end{array}$ & Ref. \\
\hline 7 & Glycine (Fig. 1g) & $\begin{array}{l}\text { Glycine }(0.3-5.0 \mathrm{~g}) \text { and sodium hydroxide } \\
(2.2 \mathrm{~g}) \text { were dissolved in } 8 \mathrm{~mL} \text { of water, and } \\
40 \mathrm{~mL} \text { of ethanol was added. The resulting } \\
\text { solution was added to a solution of } 35- \\
150 \mathrm{mg} \text { of } \mathrm{C}_{60} \text { in } 30-100 \mathrm{~mL} \text { of toluene or } \\
1,2 \text {-dichlorobenzene (or dioxane) drop by } \\
\text { drop. The solution was stirred at room tem- } \\
\text { perature, and its color changed gradually } \\
\text { from purple to dark brown. After stirring for } \\
1 \mathrm{~h} \text {, the organic layer became almost color- } \\
\text { less. The solution was stirred for } 7 \text { days to } \\
\text { ensure the reaction was complete. Its color } \\
\text { changed from violet (characteristic of } \mathrm{C}_{60} \text { in } \\
\text { toluene) to reddish brown. The aqueous layer } \\
\text { was separated from the colorless. The organic } \\
\text { layer was filtered and diluted with water to } \\
8.60 \text { mL. Ethanol was then added to precipi- } \\
\text { tate the product, which was further reprecipi- } \\
\text { tated from } \mathrm{H}_{2} \mathrm{O} / \text { EtOH. A ninhydrin test } \\
\text { showed there was no free glycine } \\
\text { in the product. A final sample was obtained } \\
\text { after drying under vacuum }\end{array}$ & $\begin{array}{l}\text { IR spectra were obtained on } \\
\text { a Perkin-Elmer FT-IR spectrometer. } \\
\text { IR }(\mathrm{KBr}): \mathrm{m} 3429,2924,1598,1492, \\
1407,1316,1119,670,520\left(\mathrm{C}_{60}\right) \mathrm{cm}^{-1} \text {. } \\
{ }^{1} \mathrm{H} \mathrm{NMR} \text { were acquired in } \mathrm{D}_{2} \mathrm{O} \text { at } \\
20^{\circ} \mathrm{C} \text { on a Bruker AM } 300 \text { spectrom- } \\
\text { eter. }{ }^{13} \mathrm{C} \mathrm{NMR} \text { were acquired in } \\
\mathrm{CDCl}_{3} \text { at } 20^{\circ} \mathrm{C} \text { on a Bruker AM } \\
\text { spectrometer }(\text { operating frequency, } \\
75 \mathrm{MHz}) .{ }^{1} \mathrm{H} \mathrm{NMR}\left(300 \mathrm{MHz}, \mathrm{D}_{2} \mathrm{O},\right. \\
\mathrm{TMS}): \delta=3.90-4.10\left(\mathrm{CH}{ }_{2} \mathrm{COO}\right), \\
5.80-6.10\left(\mathrm{C}_{60}-\mathrm{H}\right) \text { ppm; }{ }^{13} \mathrm{C} \mathrm{NMR} \\
(75 \mathrm{MHz}, \mathrm{CDCl}, \mathrm{TMS}): \\
\delta=45(\mathrm{CH}), 140-150\left(\mathrm{C}_{60}\right), \\
176(\mathrm{CO}) \text { ppm. } \mathrm{UV}-\mathrm{Vis} \text { absorption } \\
\text { spectra were recorded on a Hitachi } \\
\mathrm{U}-3300 \text { spectrophotometer. } \\
\text { Thermogravimetric analysis }(\mathrm{TGA}) \\
\text { was performed in a nitrogen atmo- } \\
\text { sphere with TA on a Q500 thermo- } \\
\text { gravimetric analyzer at } 25-1000^{\circ} \mathrm{C} \text {; } \\
\text { rate of heating, } 10 \mathrm{~K} / \mathrm{min}(\mathrm{HiRes})\end{array}$ & [51] \\
\hline 8 & $\begin{array}{l}\text { Hydroxyproline } \\
\text { (Fig. 1h) }\end{array}$ & Manufactured by ZAO ILIP (St. Petersburg) & $\begin{array}{l}99.8 \text { wt \% purity. Identification: } \\
\text { IR and UV spectroscopy, mass spec- } \\
\text { trometry, and elemental analysis }\end{array}$ & [52] \\
\hline
\end{tabular}

wide range of temperatures. The calculations were performed in a DFT harmonic approximation using the $\mathrm{DMol}^{3}$ module of Materials Studio software. $\mathrm{C}_{60}-$ Arg geometry was optimized with PBE, PW91, and

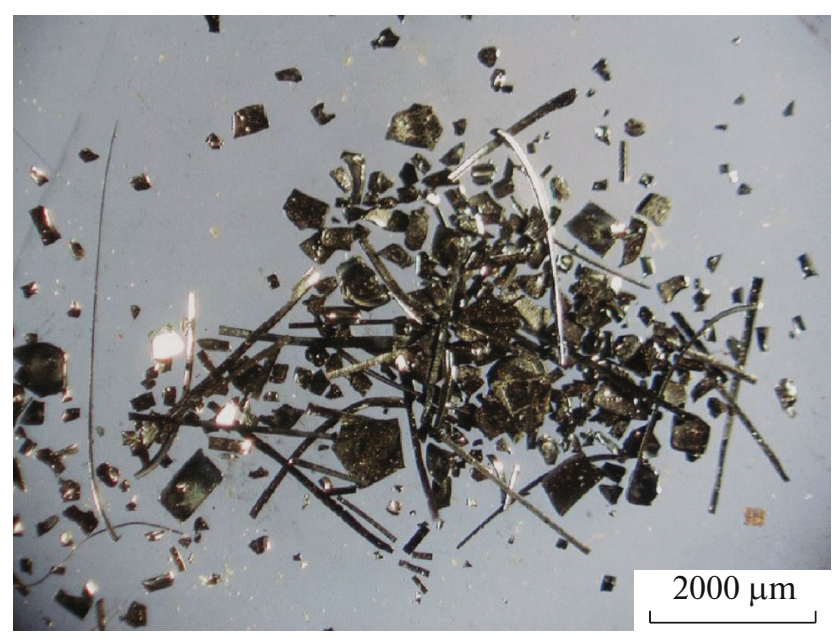

Fig. 2. Image of crystals of L-lysine $\mathrm{C}_{60}$ derivative $\left(\mathrm{C}_{60}\left(\mathrm{C}_{6} \mathrm{H}_{14} \mathrm{~N}_{2} \mathrm{O}_{2}\right)_{2}\right)$.
HCTH functionals using the DNP (4.4) full electronic atomic basis and convergence of the total energy equal $2 \times 10^{-5}$ Hartree.

Heat capacity was calculated for two types of $\mathrm{C}_{60}-$ Arg molecules with different arrangements of amino acid residues with uniform (Fig. 7a) and "Saturn-like" distributions (Fig. 7b) at temperatures of 50 to $320 \mathrm{~K}$. Results showed there was a good agreement between the calculated and experimental data at $\sim 50 \mathrm{~K}$. The systemic error grew along with temperature and was $20 \%$ at $320 \mathrm{~K}$, due to a substantial contribution from anharmonicity at high temperatures. Different isomers did not affect the heat capacity.

The electronic structure of a $\mathrm{C}_{70}$ and L-threonine derivative $\left(\mathrm{C}_{70}-\mathrm{Thr}\right)$ was calculated via DFT implemented in the $\mathrm{DMol}^{3}$ module (Materials Studio software) at the PW91 level of theory, in combination with a DNP basis (4.4) in the full electronic approach [88]. The charges of atoms were determined according to Mulliken's scheme after complete optimization of the geometry of molecules. The dynamic and the structural properties of $\mathrm{C}_{70}$, Thr, and $\mathrm{C}_{70}-\mathrm{Thr}$ were found by conventional molecular dynamics using a Forcite module with UFF force field and atomic charges cal- 


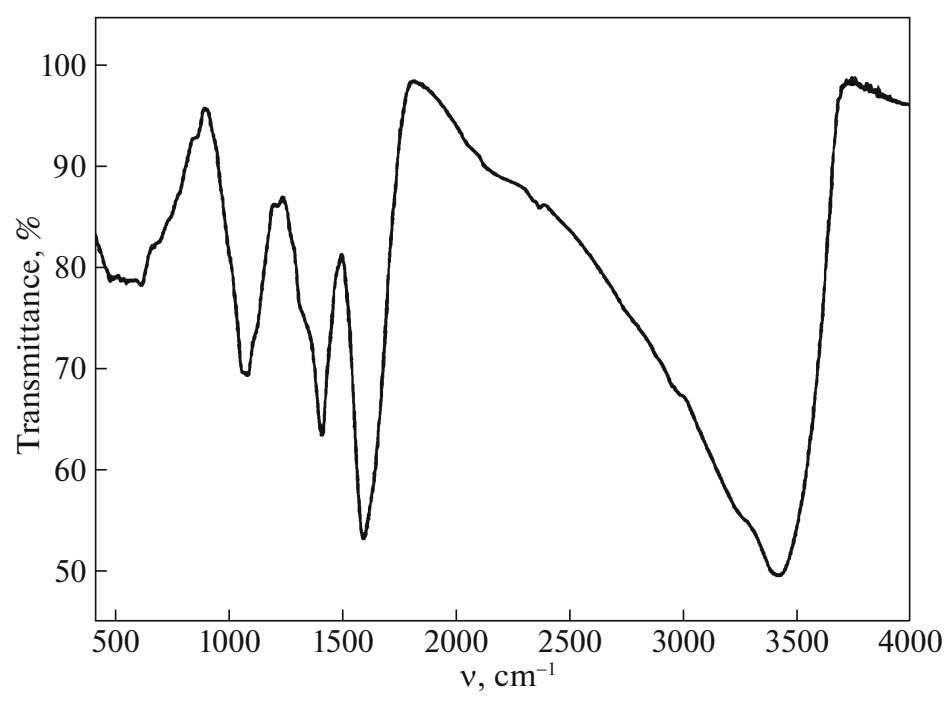

Fig. 3. IR spectrum of L-hydroxyproline $\mathrm{C}_{60}$ derivative $\left(\mathrm{C}_{60}\left(\mathrm{C}_{5} \mathrm{H}_{9} \mathrm{NO}_{3}\right)_{2}\right)$.

culated at the previous stage. Modeling took 500 ps. $\mathrm{C}_{70}-\mathrm{H}_{2} \mathrm{O}$ and $\mathrm{C}_{70}-\mathrm{Thr}-\mathrm{H}_{2} \mathrm{O}$ binary systems were modeled using 1500 water molecules per fullerene molecule and fullerene derivative. A binary system containing L-threonine was modeled using two Thr molecules and the same number of water molecules. These binary systems were studied using the NVT ensemble with MD modeling at $T=293.15 \mathrm{~K}$ and a Nose thermostat.

Figure 8 shows the electron density distributions for $\mathrm{C}_{70}$, Thr, and $\mathrm{C}_{70}-\mathrm{Thr}$ molecules, calculated with DFT. Table 3 shows the calculated atomic charges for Thr and $\mathrm{C}_{70}-\mathrm{Thr}$ molecules. The main features of the obtained results are associated with nitrogen atomic charges in amino acid and in fullerene derivative. The electronic system of fullerene probably attracted the electron pairs of nitrogen atoms and reduced all atomic charges in the amino acids. Figure 9 shows the radial distribution function (RDF) between water molecules and nitrogen atoms from amino acid (Thr) and the $\mathrm{C}_{70}-\mathrm{Thr}$ derivative. It is clear that both nitrogen atoms in the fullerene derivatives are shielded by fullerene core and amino acid residues, while individual amino acids are more accessible to water molecules. Figure 9 shows the RDF between carbon atoms of a fullerene core and water molecules. The functionalization of fullerene with two L-threonine groups is insufficient for any appreciable change in the distribution of water molecules around the fullerene core. Figure 10 shows the RDFs between water molecules and oxygen atoms of hydroxyl, carboxyl, and carbonyl groups. Analysis of the results indicates that the closest proximity of water molecules is observed for the oxygen atoms in the carbonyl group.

The shielding values for all carbon atoms of the $\mathrm{C}_{60}-\mathrm{Arg}$ molecule were calculated with DFT using the plane wave basis set in the CASTEP program to explain NMR spectra [89]. The calculations were performed with a PBE functional using a set of plane waves with cutoff value of $610 \mathrm{eV}$. The ${ }^{13} \mathrm{C}$ NMR spectra were calculated relative to tetramethylsilane. A comparison of the experimental and calculated spectra shows that the isomer with a "Saturn-like" (Fig. 7b) distribution of amino acid residues better describes the experimental spectrum (Fig. 11), as was confirmed by calculating the total energy of the isomers. The difference between the total energies of the "Saturn-like" isomer and the one with a uniform distribution of amino acid residues was $6.5 \mathrm{eV}$ (i.e., the "Saturn-like" isomer was more stable).

The conventional molecular dynamics employed in the FORCITE program of the Materials Studio software was used to calculate dynamic structure. The

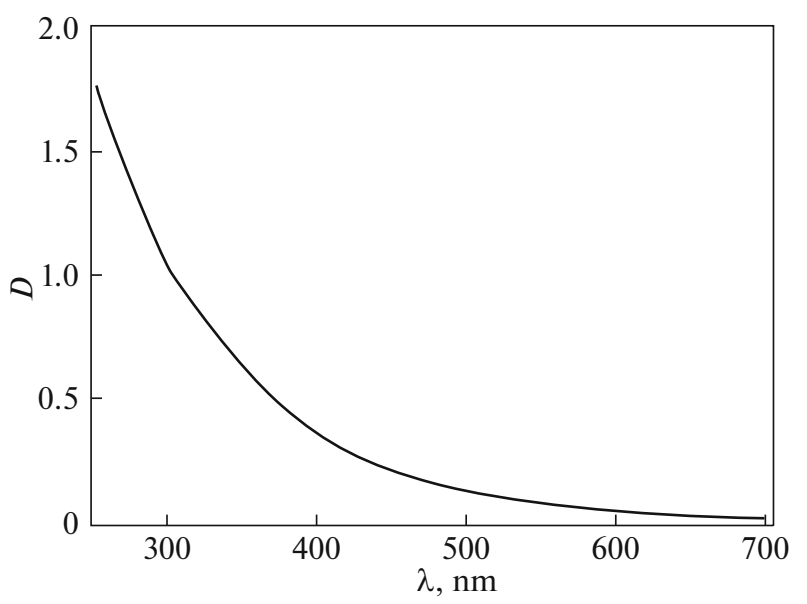

Fig. 4. Electronic spectrum of $\mathrm{L}$-arginine $\mathrm{C}_{60}$ derivative $\left(\mathrm{C}_{60}\left(\mathrm{C}_{6} \mathrm{H}_{13} \mathrm{~N}_{4} \mathrm{O}_{2}\right)_{8} \mathrm{H}_{8}\right) ; D$ is the optical density; and $\lambda$ is the wavelength. 


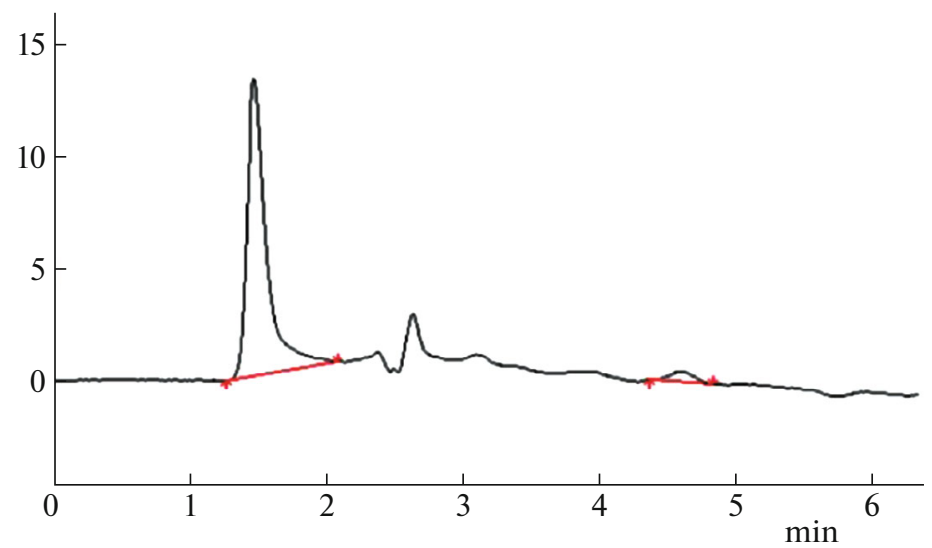

Fig. 5. Liquid chromatogram of L-threonine $\mathrm{C}_{60}$ derivative $\left(\mathrm{C}_{60}\left(\mathrm{C}_{4} \mathrm{H}_{9} \mathrm{NO}_{3}\right)_{2}\right)$. Conditions: Phenomenex® $\mathrm{NH}_{2}$ column $(150 \times$ $2.0 \mathrm{~mm}, 5 \mu \mathrm{m}, 100 \mathrm{~A})$; acetonitrile/aqueous solution of acetic acid $(0.1 \%)(5: 95)$ as the eluent at $0.2 \mathrm{~mL} / \mathrm{min}$; sample volume, $20 \mu \mathrm{L}$; diode matrix.

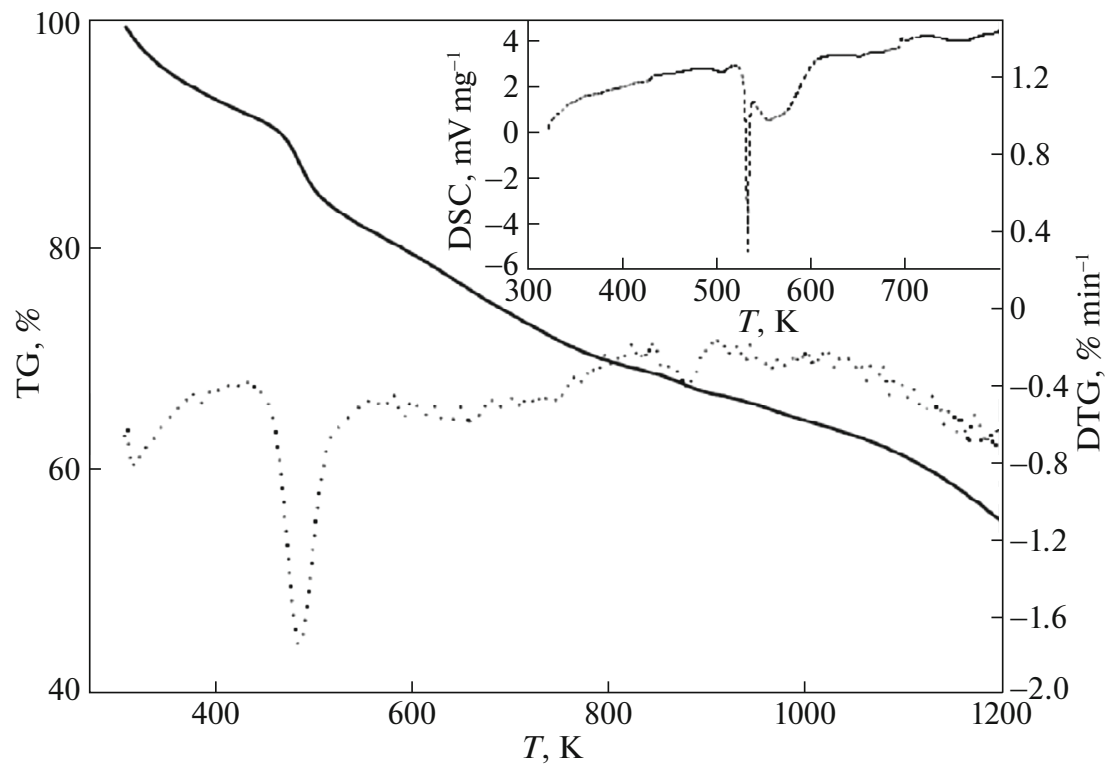

Fig. 6. Thermal analysis of a crystalline hydrate of L-lysine $\mathrm{C}_{60}$ derivative $\left(\mathrm{C}_{60}\left(\mathrm{C}_{6} \mathrm{H}_{14} \mathrm{~N}_{2} \mathrm{O}_{2}\right)_{2}\right)$.

COMPASS II force field with appropriate charges was also used. The distributions of amino acid residues over the fullerene core were found to be uniform and "Saturn-like" (Fig. 7b). A cell with periodic boundary conditions containing one $\mathrm{C}_{60}-$ Arg derivative molecule and 1500 water molecules was used in calculations. A $\mathrm{C}_{60}-\mathrm{Arg}$-water binary system was calculated at $T=300 \mathrm{~K}$ in the NVT ensemble for $1000 \mathrm{ps}$.

Molecular dynamics calculations showed that the most important property influencing interaction between the $\mathrm{C}_{60}-$ Arg derivative and water molecules was a steric factor. Figure 12 shows data of the radial distributions between each type of atom of the $\mathrm{C}_{60}-\mathrm{Arg}$ isomers ("Saturn-like" and uniform). We can see that (i) water molecules in the "Saturn-like" structure were closer to fullerene atoms than that in the uniform distribution, (ii) the oxygen atoms of the hydroxyl groups of both isomers attracted water molecules most strongly, and (iii) water molecules were closer to all atoms of the $\mathrm{C}_{60}-\mathrm{Arg}$ molecule in the "Saturn-like" isomer, due probably to the higher degree of ionicity of the "Saturn-like" isomer.

An isomer with a polar arrangement of amino acid residues of hydroxyproline $\mathrm{C}_{60}-\mathrm{Hyp}$ (Fig. 13) was selected, based on the minimum total energy calculated via DFT using the $\mathrm{DMol}^{3}$ program with a PBE functional and DNP atomic basis [90]. The charges were determined according to Mulliken's scheme. The molecular dynamics implemented in the FORCITE module of the Material Studio software was used to 
Table 2. Complex thermal analysis of $\mathrm{L}$-lysine $\mathrm{C}_{60}$ derivative $\left(\mathrm{C}_{60}\left(\mathrm{C}_{6} \mathrm{H}_{14} \mathrm{~N}_{2} \mathrm{O}_{2}\right)_{2}\right)$

\begin{tabular}{|c|c|c|c|c|}
\hline No. & $\begin{array}{c}T^{\mathrm{m}},{ }^{\circ} \mathrm{C} \\
\left(T_{\mathrm{b}}-T_{\mathrm{e}}\right),{ }^{\circ} \mathrm{C}\end{array}$ & $\Delta m_{i} / m_{0}^{\text {calc }}, \%$ & $\Delta m_{i} / m_{0}^{\exp }, \%$ & Process \\
\hline 1 & $\begin{array}{c}343.15 \\
303.15-433.15\end{array}$ & 8.2 & 8.2 & $\mathrm{C}_{60}\left(\mathrm{C}_{6} \mathrm{H}_{14} \mathrm{~N}_{2} \mathrm{O}_{2}\right)_{2} \cdot 5 \mathrm{H}_{2} \mathrm{O} \rightarrow \mathrm{C}_{60}\left(\mathrm{C}_{6} \mathrm{H}_{14} \mathrm{~N}_{2} \mathrm{O}_{2}\right)_{2}+5 \mathrm{H}_{2} \mathrm{O}$ \\
\hline 2 & $\begin{array}{c}483.15 \\
443.15-578.15\end{array}$ & 11.6 & 11.1 & $\begin{array}{l}\mathrm{C}_{60}\left(\mathrm{C}_{6} \mathrm{H}_{14} \mathrm{~N}_{2} \mathrm{O}_{2}\right)_{2}+\mathrm{O}_{2} \rightarrow \mathrm{C}_{60}\left(\mathrm{NH}\left(\mathrm{CH}_{2}\right)_{4} \mathrm{CH}_{3}\right)_{2} \\
+2 \mathrm{CO}_{2}+\mathrm{N}_{2}+2 \mathrm{H}_{2} \mathrm{O}\end{array}$ \\
\hline 3 & $\begin{array}{c}673.15 \\
593.15-793.15\end{array}$ & 11.2 & 10.6 & $\begin{array}{l}\mathrm{C}_{60}\left(\mathrm{NH}\left(\mathrm{CH}_{2}\right)_{4} \mathrm{CH}_{3}\right)_{2}+14 \mathrm{O}_{2} \rightarrow \mathrm{C}_{60}(\mathrm{NHCH}=\mathrm{O})_{2} \\
+8 \mathrm{CO}_{2}+10 \mathrm{H}_{2} \mathrm{O}\end{array}$ \\
\hline 4 & $\begin{array}{c}863.15 \\
833.15-903.15\end{array}$ & 2.4 & 2.5 & $\mathrm{C}_{60}(\mathrm{NHCH}=\mathrm{O})_{2} \rightarrow \mathrm{C}_{60} \mathrm{NH}_{2}(\mathrm{NHCH}=\mathrm{O})+\mathrm{CO}$ \\
\hline 5 & $\begin{array}{c}963.15 \\
903.15-1033.15\end{array}$ & 2.9 & 2.5 & $\mathrm{C}_{60} \mathrm{NH}_{2}(\mathrm{NHCH}=\mathrm{O}) \rightarrow \mathrm{C}_{60}\left(\mathrm{NH}_{2}\right)_{2}+\mathrm{CO}$ \\
\hline 6 & $\begin{array}{c}1073.15 \\
1053.15-1093.15\end{array}$ & 2.8 & 2.8 & $\mathrm{C}_{60}\left(\mathrm{NH}_{2}\right)_{2}+\mathrm{O}_{2} \rightarrow \mathrm{C}_{60}+2 \mathrm{H}_{2} \mathrm{O}+\mathrm{N}_{2}$ \\
\hline 7 & $\begin{array}{c}1203.15 \\
109.15-1323.15\end{array}$ & $>14$ & $>14$ & Partial oxidation of $\mathrm{C}_{60}$ \\
\hline
\end{tabular}

$T_{\mathrm{m}}$ is the temperature of the maximum thermal effect; $T_{\mathrm{b}}$ and $T_{\mathrm{e}}$ the temperatures at the start and end of the thermal effect; $\Delta m_{i} / m_{0}$ is the mass loss; and $m_{0}$ is the initial mass [87].

determine the arrangement of water molecules in a $\mathrm{C}_{60}-$ Hyp aqueous medium. The modeled system contained one $\mathrm{C}_{60}-$ Hyp molecule and 3000 water molecules. An NVT ensemble, 5 ns duration, a 1 fs time step at $T=298.15 \mathrm{~K}$, and a UFF force field with calculated charges were used in calculations. Table 4 gives atomic charges $a-f$ (Fig. 14).

Results from computer modeling with molecular dynamics (Fig. 13) showed that water molecules were closest to the oxygen atoms of carboxyl groups ( 3.25 and $3.21 \AA$ ) (Fig. 14, $d, e$ ), due to the combined actions of two closely located oxygen atoms; this was not observed for the more charged single oxygen atoms of the hydroxyl groups $(3.31 \AA$ ) (Fig. 14, a). The maximum RDF value of water molecules relative to the carbon atom of a fullerene core (Fig. 14, $b$ ) shows that water molecules come closer to this atom much less than the oxygen atoms of an amino acid residue. Nitrogen atoms $(5.55 \AA$ Å) (Fig. 14, c) have almost no contact with water molecules, due to steric hindrances.

Compounds in which an amino acid is not bound to a fullerene by a chemical bond and a stable complex forms through noncovalent interactions have been studied in some works on the computer modeling of amino acid fullerenes adducts. Only interactions between pristine fullerene and amino acid molecules were analyzed in these works, although fullerene cores modified with different atoms and functional groups were calculated as well.

DFT was used in combination with the $6-31 \mathrm{G}(d)$ basis set to calculate adsorption complexes of fullerene and phenylalanine in the gas phase and in water at the
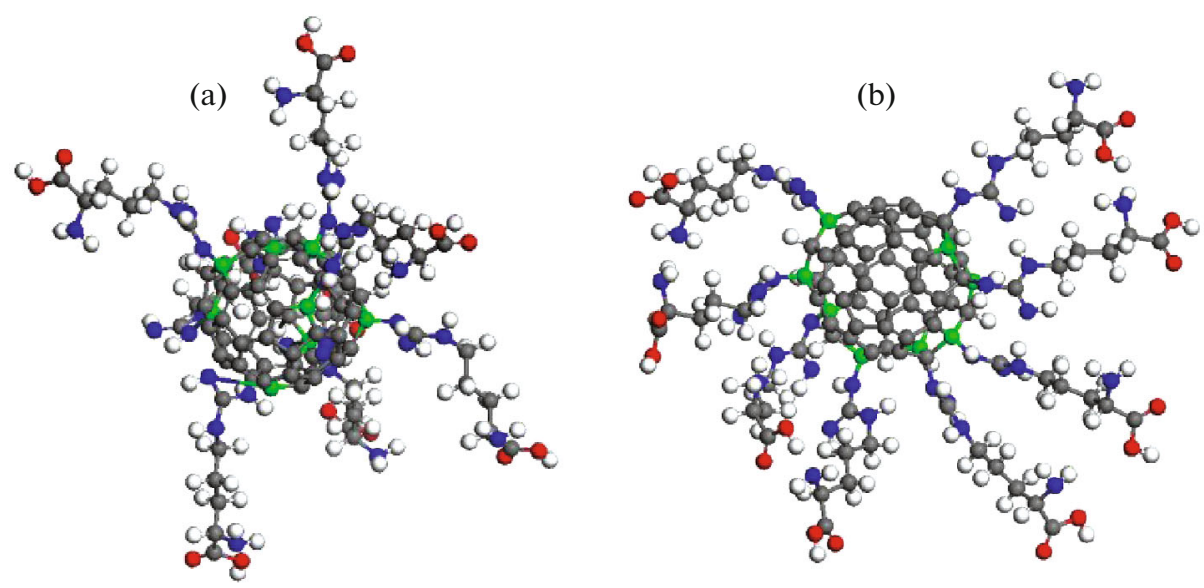

Fig. 7. $\mathrm{C}_{60}-$ Arg fullerene derivative with (a) uniform and (b) "Saturn-like" arrangements of amino acid residues. 
(a)

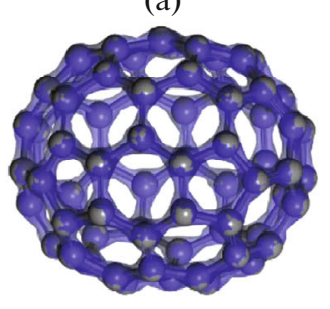

(b)

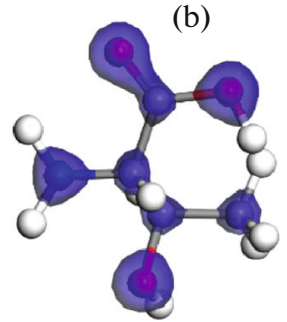

(c)

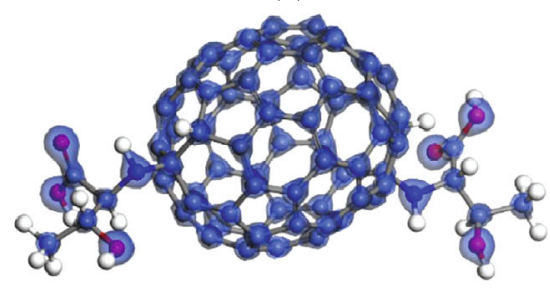

Fig. 8. Distribution of electron density in (a) fullerene $C_{70}$, (b) threonine, and (c) $\mathrm{C}_{70}-$ Thr derivative.

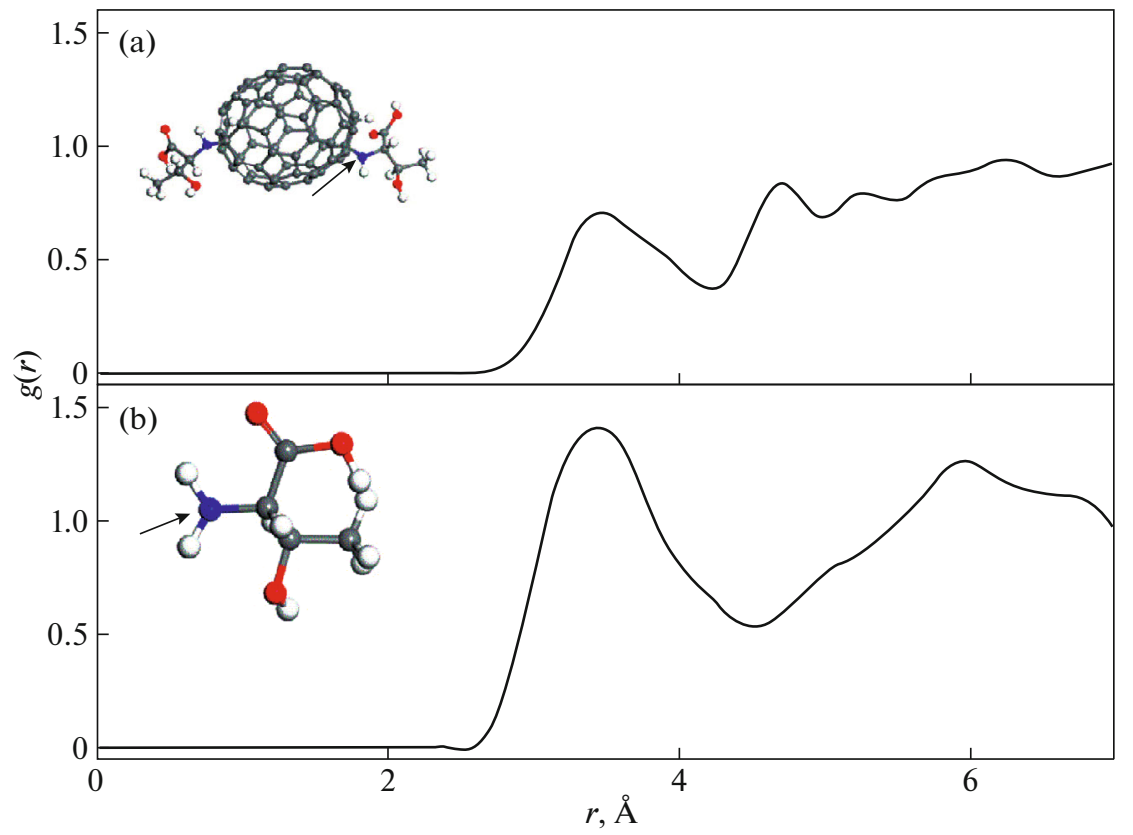

Fig. 9. Radial distribution functions between water molecules and nitrogen atoms in (a) $\mathrm{C}_{70}-\mathrm{Thr}$ and (b) threonine molecules.

M062X and B3LYP levels of theory [91]. Kaya et al. showed that the energy of bonds between an amino acid and fullerene at four probable sites of adsorption of a phenylalanine molecule depends on the electron density distribution after complete optimization of the geometry of the complex. The distances between a phenylalanine molecule and a fullerene core (M062X functional) were 3.61 and $3.60 \AA$ in the gas phase and water, respectively, and 4.38 and $4.45 \AA$ for a B 3 LYP functional.

Table 3. Average charges (in electron charge units) of nitrogen and oxygen atoms of hydroxyl $(-\mathrm{OH})$, carboxyl $(-\mathrm{COOH})$, and carbonyl $(\mathrm{C}=\mathrm{O})$ groups, determined according to Mulliken's scheme

\begin{tabular}{l|c|c|c|c}
\hline System & $\mathrm{O}(-\mathrm{COOH})$ & $\mathrm{O}(-\mathrm{OH})$ & $\mathrm{O}(-\mathrm{C}=\mathrm{O})$ & $\mathrm{N}$ \\
\hline $\mathrm{Thr}$ & -0.632 & -0.660 & -0.337 & -0.743 \\
$\mathrm{C}_{70}-\mathrm{Thr}$ & -0.420 & -0.496 & -0.398 & -0.268 \\
\hline
\end{tabular}

The interaction between $\mathrm{C}_{60}$ fullerene and an L-histidine molecule was modeled computationally [92]. RHF/6-31G* was used to calculate the electronic structure and for complete geometry optimization. The energy of interaction between the amino acid molecule and the fullerene core was determined at the MP2 level of theory. The distance between the hydrogen atoms of the amino acid molecule, which have a weakly positive charge, and the atoms of the fullerene molecule were 3.0-3.1 $\AA$.

The noncovalent interaction between $20 \mathrm{~L}$-amino acids and $\mathrm{C}_{60}$ fullerene core was studied via DFT (the $\mathrm{DMol}^{3}$ module of the Materials Studio software) using the PBE functional, DNP basis, and Grimme correction for noncovalent interactions [93]. The geometry of the complexes in the gas phase and water was completely optimized, and the total energy of the system was calculated. The energies of formation of complexes in vacuum and water were analyzed comparatively in this work. The limited nature of the approach, according to which the interaction between amino 


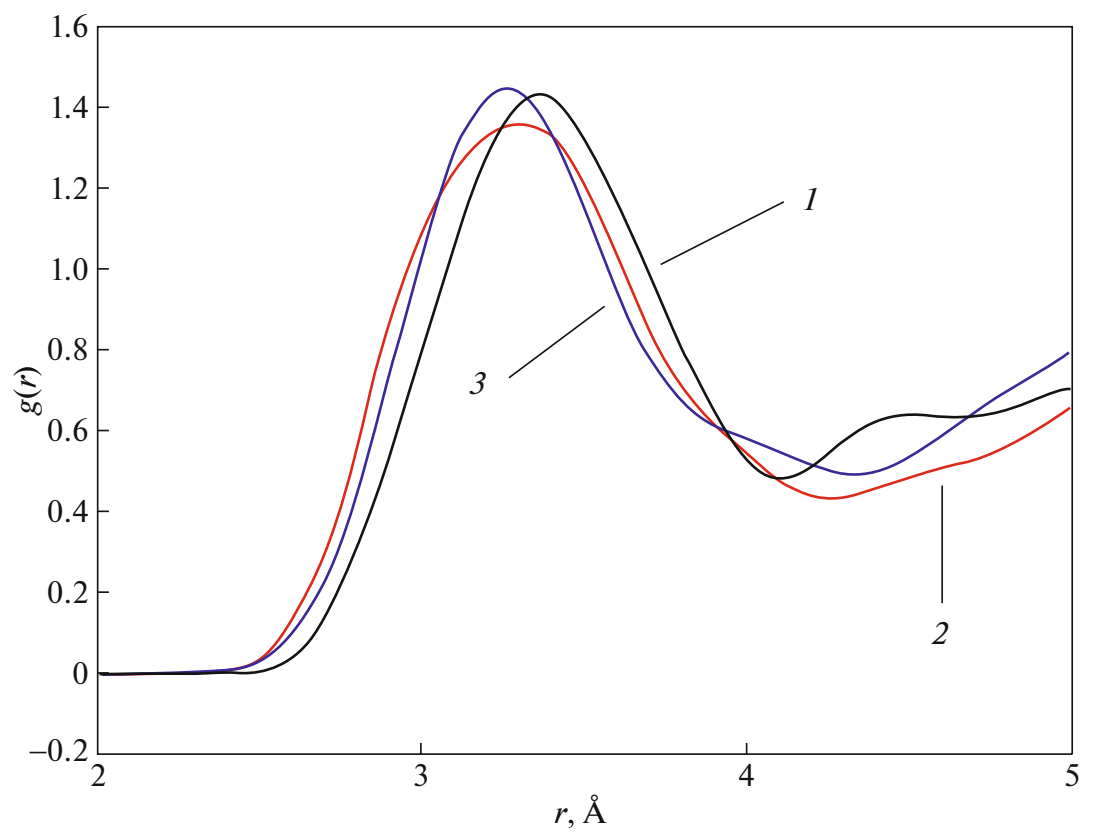

Fig. 10. Radial distribution functions between water molecules and oxygen atoms of: (1) hydroxyl, (2) carboxyl, and (3) carbonyl groups.
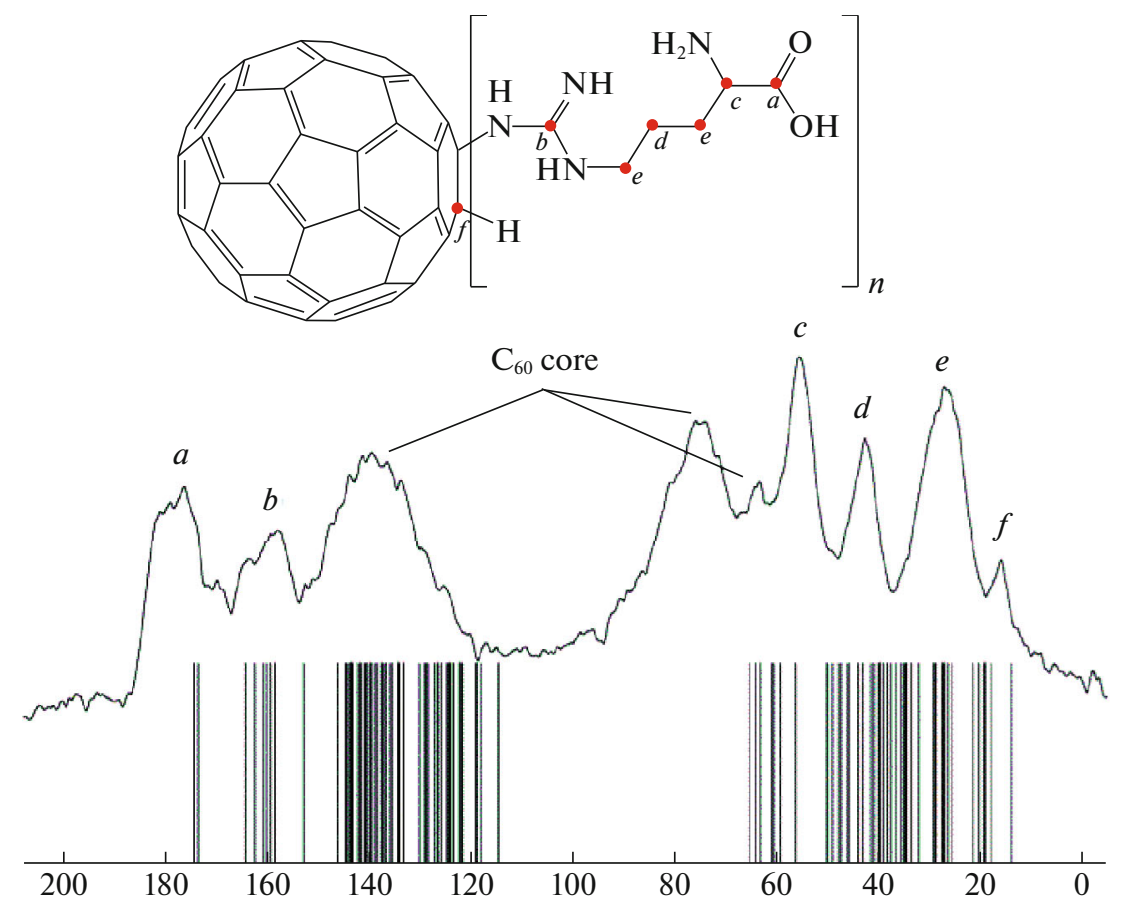

Fig. 11. ${ }^{13} \mathrm{C}$ NMR experimental spectrum obtained via CP/MAS (contact time, $2 \mathrm{~ms}$ ) and calculated with DFT.

acid molecule and fullerene core obeys a hydrophobic mechanism, was demonstrated.

Interaction between proline molecules and the surfaces of $\mathrm{C}_{60}$ fullerene cores was studied in [94]. The B3LYP/6-31G $(d)$ approach employed in Spartan was used in calculations. The optimum geometry (bond lengths), IR spectra in the range of 298.15-
$398.15 \mathrm{~K}$, the energy of adsorption, and the orbital energies of HOMO and LUMO were calculated. It was shown that the adsorption of proline on a fullerene core is endothermic and impossible in actual experiments.

An effective way of calculating the $\mathrm{p} K_{\mathrm{a}}$ of a L-alanine- $\mathrm{C}_{60}$ adduct by quantum-chemical means was 


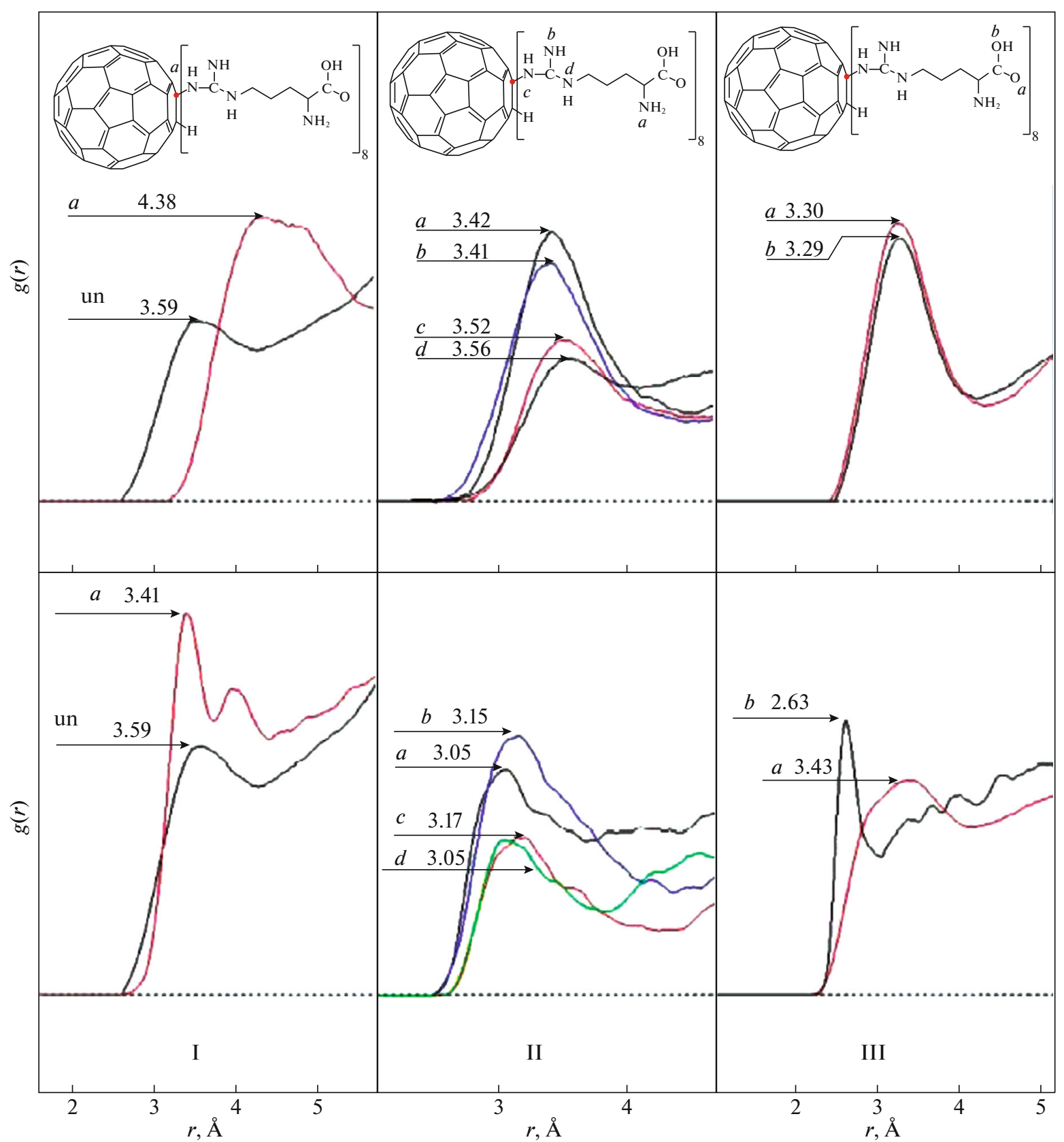

Fig. 12. Radial distribution function for the oxygen atoms of water and different atoms of $C_{60}-\operatorname{Arg}$ derivative: (I) carbon atoms of a fullerene core; (II) nitrogen atoms of arginine residues; (III) oxygen atoms of arginine residues. The upper graphs correspond to uniform distributions of functional groups; the lower ones, to "Saturn-like" distributions; un-unmodified fullerene.

proposed in [95]. HF and DFT (Gaussian software) were used in combination with the 6-31G $(d)$ basis set and B3LYP functional to calculate the equilibrium geometry and vibrational frequencies in the gas phase. The energies of hydration and the electron energies in water were then calculated using the PCM continuum model. The isomers of the adduct were considered in detail, and the one most energetically favorable was found. It was shown that the formation of $\mathrm{COO}^{-}-$
$\mathrm{CH}(\mathrm{Me})-\mathrm{NH}_{2}^{+}-\mathrm{C}_{60} \mathrm{H}$ and $\mathrm{COOH}-\mathrm{CH}(\mathrm{Me})-$ $\mathrm{NH}_{2}^{+}-\mathrm{C}_{60}^{-}$zwitterions with negative charges localized on $\mathrm{COO}^{-}$or $\mathrm{C}_{60}^{-}$was quite impossible.

DFT was used to calculate the energies of interaction between fullerene and peptides from lysine and alanine using the BLYP and VWN functionals in combination with the DNP basis set (the $\mathrm{DMol}^{3}$ module of the Materials Studio package) [96]. The authors 


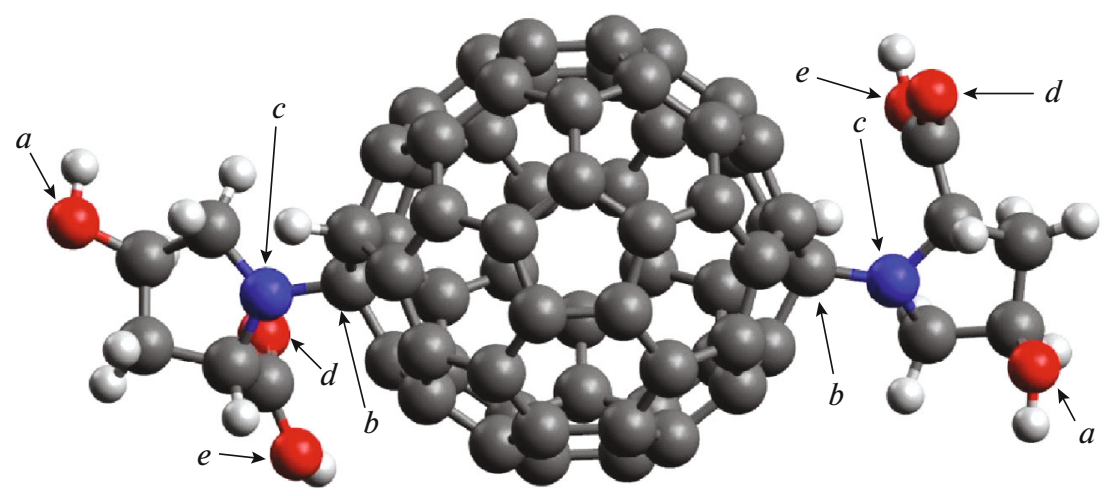

Fig. 13. $\mathrm{C}_{60}-$ Hyp isomer with polar arrangement of amino acid residues. Letters $a-e$ correspond to atoms shown in Table 4 .

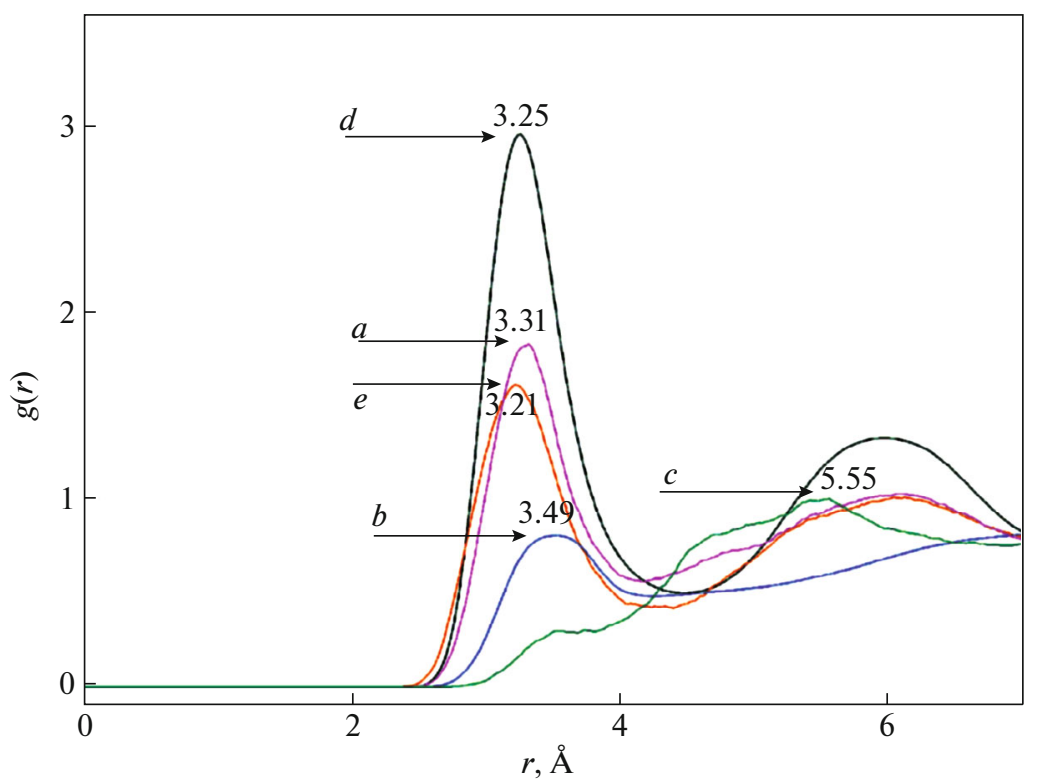

Fig. 14. Radial distribution functions of different atoms in $\mathrm{C}_{60}-\mathrm{Hyp}$ : $(a)$ oxygen of the hydroxyl group; $(b)$ carbon atoms of the modified fullerene core; $(c)$ nitrogen atom; $(d)$ oxygen atom of the carbonyl group; $(e)$ oxygen atom of the carboxyl group.

showed that the BLYP functional cannot be used to model such systems, while the VWN functional gives reliable and somewhat underestimated values. Molecular mechanics was used, and the AMBER and $\mathrm{MM}^{+}$ force fields (HyperChem package) were studied in [96]. The best results were obtained for the AMBER force field. Such calculations clearly demonstrate the possibilities of using computational means to study the interaction between protein molecules and fullerene.

The adsorption of alanine on fullerene $\mathrm{C}_{60}$ was modeled via DFT [97]. A model complex was optimized using the M062X functional and the 6-31G* basis set (Gaussian program). The energies of adsorption, reactivity indices, atomic charges, and global electron density transfer (GEDT) in the gaseous and aqueous phases were calculated. It was shown that a stable compound formed at distances of 3.03-3.07 between an alanine molecule and a fullerene core.

The noncovalent interactions of glycine encapsulated into a $\mathrm{C}_{60}$ fullerene were studied in [98]. The M06-2X functional and 6-311G $(d, p)$ basis set were

Table 4. Calculated atomic charges (in electron charges) of the $\mathrm{C}_{60}-$ Hyp derivative used in calculations with molecular dynamics ( $a-f$, Fig. 13)

\begin{tabular}{c|c}
\hline Atom & Charges \\
\hline $\mathrm{O}(a)$ & -0.570 \\
$\mathrm{C}(b)$ & 0.187 \\
$\mathrm{~N}(c)$ & -0.561 \\
$\mathrm{O}(d)$ & -0.450 \\
$\mathrm{O}(e)$ & -0.455 \\
\hline
\end{tabular}


used. Results from calculations showed that the fullerene core strongly affects the structure and the electronic properties of a glycine molecule inside it. The amino acid molecule is deformed and tends to form a zwitterion, despite strong repulsion from fullerene carbon atoms, and the spatial arrangement of a glycine molecule is due to the interaction between nitrogen atoms and the fullerene's electronic system.

The energies of hydration of aspartic acid and methionine fullerene adducts were calculated in [99]. Products consisting of a fullerene core and five homogeneous amino acid residues were considered. The energy of hydration was calculated via DFT using both the UA and PCM approaches to the continuous monitoring of the medium and a generalized Born procedure. The charges on atoms were found according to Mulliken's scheme following calculations at the B3LYP level of theory, in combination with the 6-31G $(d)$ and $6-31+\mathrm{G}(d, p)$ basis sets. The energy of hydration for neutral and charged fullerene $\mathrm{C}_{60}$ amino acid adducts was reproduced quite well using the generalized Born procedure.

The adsorption of aminolevulinic acid with fullerene $\mathrm{C}_{60}$ was modeled in [100]. DFT calculations were performed using the GAMESS program at the B3LYP level of theory, in combination with the $6-31 \mathrm{G}^{*}$ basis set. Calculations showed that electrostatic energy plays an important role in the adsorption of amino acids, while the electronic properties and geometric structure of a fullerene core change negligibly.

Modern computational modeling at the atomicmolecular level thus allows us to better understand both electronic and structural features of amino acid fullerene derivatives and their physicochemical properties.

\section{FUNDING}

This work was supported by the Russian Foundation for Basic Research, project 20-13-50017 Ekspansiya.

\section{OPEN ACCESS}

This article is licensed under a Creative Commons Attribution 4.0 International License, which permits use, sharing, adaptation, distribution and reproduction in any medium or format, as long as you give appropriate credit to the original author(s) and the source, provide a link to the Creative Commons license, and indicate if changes were made. The images or other third party material in this article are included in the article's Creative Commons license, unless indicated otherwise in a credit line to the material. If material is not included in the article's Creative Commons license and your intended use is not permitted by statutory regulation or exceeds the permitted use, you will need to obtain permission directly from the copyright holder. To view a copy of this license, visit http://creativecommons.org/licenses/by/4.0/.

\section{REFERENCES}

1. H. W. Kroto, J. R. Heath, S. C. O'Brien, et al., Nature (London, U.K.) 318 (6042), 162 (1985).

2. R. S. Ruoff, D. S. Tse, R. Malhorta, and D. S. Lorents, J. Phys. Chem. 97, 3379 (1993).

3. L. N. Sidorov and M. A. Yurovskaya, Fullerens, The School-Book (Ekzamen, Moscow, 2005) [in Russian].

4. L. B. Piotrovskii and O. I. Kiselev, Fullerens in Biology, The School-Book (Rostok, St. Petersburg, 2006) [in Russian].

5. K. N. Semenov, N. A. Charykov, and V. A. Keskinov, J. Chem. Eng. Data 55, 13 (2010).

6. K. N. Semenov, N. A. Charykov, and V. A. Keskinov, Russ. J. Phys. Chem. A 87, 54 (2013).

7. K. N. Semenov, N. A. Charykov, V. A. Keskinov, A. K. Pyartman, and O. V. Arapov, Russ. J. Appl. Chem. 83, 997 (2010).

8. G. V. Andrievsky, M. V. Kosevich, O. M. Vovk, et al., J. Chem. Soc. 12, 1281 (1995).

9. Z. N. Parnes, V. S. Romanova, S. M. Andreev, et al., RF Patent No. 2129436 (1999).

10. T. Andersson, K. Nilsson, M. Sundahl, et al., J. Chem. Soc., Chem. Commun., p. 604 (1992).

11. Y. N. Yamakoshi, T. Yagami, K. Fukuhara, et al., J. Chem. Soc., Chem. Commun., p. 517 (1994).

12. T. Nakanishi, K. Ariga, M. Morita, et al., Colloids Surf., A 284-285, 607 (2006).

13. S. M. Andreev, E. N. Bashkatova, Yu. N. Bashkatova, et al., RF Patent and No. 2462474, Byull. Izobret., No. 27 (2012).

14. M. A. Yurovskaya, Soros. Obrazov. Zh., No. 5, 26 (2000).

15. A. Hirsch, Q. Li, and F. Wudi, Angew. Chem., Int. Ed. Engl. 30, 309 (1991).

16. V. S. Romanova, V. A. Tsyryapkin, Yu. A. Lyakhovetskii, et al., Russ. Chem. Bull. 43, 1090 (1994).

17. O. V. Masalova, A. V. Shepelev, S. N. Atanadze, et al., Dokl. Akad. Nauk 369, 411 (1999).

18. M. G. Medzhidova, M. V. Abdullaeva, N. E. Fedorova, et al., Antibiot. Khimioter. 49 (8-9), 13 (2004).

19. S. M. Andreev, A. A. Babakhin, A. O. Petrukhina, et al., Dokl. Biochem. 370, 4 (2000).

20. S. H. Friedman, D. L. DeCamp, R. Sijbesma, et al., J. Am. Chem. Soc. 115, 6506 (1993).

21. R. Sijbesma, G. Srdanov, F. Wudl, et al., J. Am. Chem. Soc. 115, 6510 (1993).

22. R. F. Schinazi, R. Sijbesma, G. Srdano, et al., Antimicrob. Agents Chemother. 37, 1707 (1993).

23. F. Wudl, Y. Rubin, and G. L. Kenyon, Proc. Electrochem. Soc. 24, 662 (1994).

24. R. F. Schinazi, A. McMillan, A. S. Juodawlkis, et al., Proc. Electrochem. Soc. 24, 689 (1994).

25. D. J. Triggle, Chemtracts: Org. Chem. 7,57 (1994).

26. R. F. Schinazi, C. Bellavia, R. Gonzalez, et al., Proc. Electrochem. Soc. 10, 696 (1995).

27. L. Y. Chiang, L.-Y. Wang, J. W. Swirczewski, et al., Org. Chem. 59, 3960 (1994).

28. F. Wudl, A. Hirsch, K. Khemani, et al., ACS Symp. Ser. 481, 161 (1992). 
29. S. M. Andreev, V. P. Laptev, N. G. Panferova, et al., RF Patent No. 2323722, Byull. Izobret., No. 13 (2008).

30. S. M. Andreev, E. N. Bashkatova, M. R. Khaitov, and D. D. Purgina, RF Patent No. 2548971, Byull. Izobret., No. 11 (2015).

31. J. Li, A. Takeuchi, and M. Ozawa, J. Chem. Soc. Chem. Commun. 23, 1784 (1993).

32. L. Y. Chiang, J. Bhonsle, L. Wang, et al., Tetrahedron 52, 4963 (1996).

33. L. Y. Chiang, R. Upasani, and J. W. Swirczewski, J. Am. Chem. Soc. 114, 10154 (1992).

34. M. S. Meier and J. Kiegiel, Org. Lett. 3, 1717 (2001).

35. L. Szymanska, H. Radecka, J. Radecki, et al., Biosens. Bioelectron. 16, 911 (2001).

36. S. M. Mirkov, A. N. Djordjevic, N. L. Andric, et al., Nitric Oxide 11, 201 (2004).

37. K. Kokubo, K. Matsubayashi, H. Tategaki, et al., ACS Nano 2, 327 (2008).

38. J. M. Yang, W. He, H. Ping, et al., Chin. J. Chem. 22, 1008 (2004).

39. W. Sheng, H. Ping, Z. Jian-Min, et al., Synth. Commun. 35, 1803 (2005).

40. Y. Chiang Long, US Patent No. 5648523 (1997).

41. I. Lamparth and A. Hirsch, J. Chem. Soc., Chem. Commun., 1727 (1994).

42. A. A. Shestopalova, V. A. Keskinov, V. V. Klepikov, et al., J. Mol. Liq. 211, 301 (2015).

43. A. A. Shestopalova, N. A. Charykov, S. S. Kalacheva, and K. N. Semenov, in Chemistry and Chemical Education of the XXI Century, Collection of Articles (2015), p. 96.

44. R. A. Kotelnikova, A. I. Kotelnikov, G. N. Bogdanov, et al., FEBS Lett. 389, 111 (1996).

45. M. E. Vol'pin, E. M. Belavtseva, V. S. Romanova, et al., Mendeleev Commun. 4, 129 (1995).

46. Z. Hu, W. Guan, W. Wang, et al., Carbon 46, 99 (2008); Cell Biol. Int. 31, 798 (2007).

47. I. C. Wang, L. A. Tai, Lee, et al., J. Med. Chem. 42, 4614 (1999). https://doi.org/10.1021/jm990144s

48. L. B. Gan and C. P. Luo, Chin. Chem. Lett. 5, 275 (1994).

49. Z. Hu, W. Guan, W. Wang, et al., Chem.-Biol. Interact. 167, 135 (2007).

50. A. Kumar, M. V. Rao, and S. K. Menon, Tetrahedron Lett. 50, 6526 (2009).

51. G. Jiang, F. Yi, J. Duan, and G. Li, J. Mater. Sci.: Mater. Med. 26, 1 (2015).

52. K. N. Semenov, A. A. Meshcheriakov, N. A. Charykov, et al., RSC Adv., No. 7, 15189 (2017).

53. A. Djordjevic, B. Srdjenovic, M. Seke, et al., J. Nanomater. 2015, 567073 (2015).

54. S. H. Friedman, R. F. Schinazi, F. Wudl, et al., US Patent No. US6613771B2 (2001).

55. M. N. Zhmak, O. M. Vol'pina, M. A. Kupriyanova, et al., RF Patent No. 2124022 (1998).

56. A. Leon, A. F. Jalbout, and V. A. Basiuk, Chem. Phys. Lett. 452, 306 (2008).

57. T. Yu. Dolinina and V. B. Luzhkov, Russ. Chem. Bull 61, 1631 (2012).
58. K. N. Semenov, N. A. Charykov, I. V. Murin, and Yu. V. Pukharenko, J. Mol. Liq. 202, 50 (2015).

59. K. N. Semenov, N. M. Ivanova, N. A. Charykov, V. A. Keskinov, S. S. Kalacheva, N. N. Duryagina, P. V. Garamova, N. A. Kulenova, and A. Nabieva, Russ. J. Phys. Chem. A 91, 315 (2017).

60. B. A. Noskov, K. A. Timoshen, A. V. Akentiev, et al., Colloids Surf., A 529, 1 (2017).

61. M. I. Lelet, K. N. Semenov, and E. V. Andrusenko, J. Chem. Thermodyn. 115, 7 (2017).

62. K. N. Semenov, N. A. Charykov, and A. A. Meshcheriakov, J. Mol. Liq. 242, 940 (2017).

63. K. N. Semenov, E. V. Andrusenko, N. A. Charykov, et al., Prog. Solid State Chem. 47-48, 16 (2017).

64. E. B. Serebryakov, K. N. Semenov, and I. V. Stepanyuk, J. Mol. Liq. 256, 507 (2018).

65. G. O. Iurev, M. I. Lelet, E. A. Pochkayeva, et al., J. Chem. Thermodyn. 127, 39 (2018).

66. G. A. Burley, P. A. Keller, and G. S. Pyne, Full. Sci. Techol. 7, 973 (1999).

67. A. Bianco, T. Da Ros, M. Prato, and S. Toniolo, J. Pept. Sci. 7, 208 (2011).

68. L. Gan, D. Zhou, C. Luo, et al., Org. Chem. 61, 1954 (1996).

69. Z. S. Klemenkova, V. S. Romanova, V. A. Tsyryapkin, et al., Mendeleev Commun. 6, 602 (1996).

70. R. F. Enes, A. C. Tome, and J. A. S. Cavaleiro, Tetrahedron 61, 1423 (2005).

71. L. A. Watanabe, M. P. I. Bruiyan, B. Jose, et al., Tetrahedron Lett. 45, 7137 (2004).

72. A. Varon and F. Naide, Crit. Rev. Biochem. Mol. Biol. 28, 31 (1993).

73. A. Bianco, V. Lucchini, and M. Maggini, J. Peptide Sci. 4, 364 (1998).

74. A. Bianco, T. Bertolini, M. Crisma, et al., J. Peptide Sci. 50, 159 (1997).

75. L. D. Rasnetsov, Ya. Yu. Shvartsman, I. K. Lyalina, et al., RF Patent No. 2213039, Byull. Izobret., No. 27 (2003).

76. A. I. Kotel'nikov, V. S. Romanova, G. N. Bogdanov, et al., RF Patent No. 2462473, Byull. Izobret., No. 27 (2012).

77. T. V. Magdesieva, O. A. Levitskii, A. A. Ambartsumyan, and K. A. Kochetkov, RF Patent No. 2614247, Byull. Izobret., No. 9 (2017).

78. L. V. Tat'yanenko, O. V. Dobrokhotova, R. A. Kotel'nikova, et al., Pharm. Chem. J. 45, 329 (2011).

79. K. N. Semenov, N. A. Charykov, V. Postnov, et al., Russ. Chem. Rev. 85, 38 (2016).

80. Q. Liu, X. Zhang, X. Zhang, et al., ACS Appl. Mater. Interfaces 5, 11101 (2013).

81. Q. Liu, J. Zheng, M. Guan, et al., ACS Appl. Mater. Interfaces 5, 4328 (2013).

82. L. D. Rasnetsov, RF Patent No. 2236852, Byull. Izobet., No. 27 (2004).

83. L. B. Piotrovskii, Ross. Nanotekhnol. 2 (7-8), 6 (2007).

84. V. V. Grigoriev, L. N. Petrova, T. A. Ivanova, et al., Biol. Bull. 38, 125 (2011). 
85. R. A. Kotel'nikova, I. I. Faingol'd, D. A. Poletaeva, et al., Russ. Chem. Bull. 6, 1172 (2011).

86. A. W. Jensen, S. R. Wilson, and D. I. Schuster, Bioorg. Med. Chem. 4, 767 (1996).

87. K. N. Semenov, Doctoral Dissertation in Chemistry (SPb. State Univ., St. Petersburg, 2016).

88. E. B. Serebryakov, D. N. Zakusilo, K. N. Semenov, et al., J. Mol. Liq. 279, 687 (2019). https://doi.org/10.1016/j.molliq.2019.02.013

89. S. V. Ageev, G. O. Iurev, N. E. Podolsky, et al., J. Mol. Liq. 291, 111256 (2019). https://doi.org/10.1016/j.molliq.2019.111256

90. A. A. Meshcheriakov, G. O. Iurev, M. D. Luttsev, et al., Colloids Surf., B 196, 111338 (2020).

91. M. F. Kaya, O. Alver, C. Parlak, and P. Ramasami, Main Group Met. Chem. 42, 135 (2019).

92. B. Lal, J. Mol. Model. 13, 531 (2007). https://doi.org/10.1007/s00894-007-0179-6

93. V. A. Basiuk and E. González-Luciano, Fullerenes, Nanotubes Carbon Nanostruct. 24, 371 (2016). https://doi.org/10.1080/1536383X.2016.1163687
94. R. Ahmadi, M. R. J. Sarvestani, R. Taghavizad, and N. Rahim, Chem. Methodolol. 4, 68 (2020).

95. V. B. Luzhkov, V. S. Romanova, and A. I. Kotelnikov, Russ. Chem. Bull. 63, 567 (2014).

96. V. A. Basiuk and M. Bassiouk, J. Comput. Theor. Nanosci. 8, 243 (2011).

97. H. D. Khavidaki and M. Soleymani, Phys. Chem. Res. 8, 657 (2020). https://doi.org/10.22036/pcr.2020.227279.1759

98. M. Shahamirian and S. M. Azami, Phys. Lett. A 383, 126004 (2019). https://doi.org/10.1016/j.physleta.2019.126004

99. V. B. Krapivin and V. B. Luzhkov, IOP Conf. Ser.: Mater. Sci. Eng. 525, 012033 (2019). https://doi.org/10.1088/1757-899X/525/1/012033

100. M. Kiaa, M. Golzar, K. Mahjoub, and A. Soltani, Superlatt. Microstruct. 62, 251 (2013). https://doi.org/10.1016/j.spmi.2013.07.010

Translated by A. Tulyabaev 